\title{
Industrial derivative of tallow: a promising renewable substrate for microbial lipid, single-cell protein and lipase production by Yarrowia lipolytica
}

\author{
Seraphim Papanikolaou* \\ Department of Food Science and Technology \\ Agricultural University of Athens \\ 75 Iera Odos, 11855-Athens, Greece \\ Tel: 302105294700 \\ Fax: 302105294700 \\ E-mail: spapanik@aua.gr \\ Isabelle Chevalot \\ Laboratoire des Sciences du Génie Chimique \\ C.N.R.S. - E.N.S.I.C./E.N.S.A.I.A \\ U.P.R. 6811, 13, rue du Bois de la Champelle \\ 54500 - Vandœuvre-Lès-Nancy, France \\ E-mail: Isabelle.Chevalot@ensaia.inpl-nancy.fr
}

Maria Galiotou-Panayotou

Department of Food Science and Technology

Agricultural University of Athens

75 Iera Odos, 11855 - Athens, Greece

E-mail:mgal@aua.gr

Michael Komaitis

Department of Food Science and Technology

Agricultural University of Athens

75 Iera Odos, 11855-Athens, Greece

E-mail: achem@aua.gr

Ivan Marc

Laboratoire des Sciences du Génie Chimique C.N.R.S. - E.N.S.I.C./E.N.S.A.I.A

U.P.R. 6811, 13, rue du Bois de la Champelle 54500 - Vandouvre-Lès-Nancy, France

E-mail: Ivan.Marc@ensic.inpl-nancy.fr

\author{
George Aggelis \\ Department of Biology \\ Division of Genetics, Cell and Development Biology \\ University of Patras \\ 26500-Patras, Greece \\ E-mail: George.Aggelis@upatras.gr
}

Financial support: The present work was partially financed by the international cooperation project in industrial research activities of development in precompetitive stage- 2005 (О $\Delta$ ВВЕПРО-69) entitled "Exploitation of the natural microflora of the olive fruit for the production of virgin oil of high quality" (General Secretariat of Research and Development of the Greek Ministry of Development - E.U.)

Keywords: lipase, microbial lipids, single-cell protein, tallow, Yarrowia lipolytica.

Abbreviations: $\alpha(\mathrm{IU} / \mathrm{mg})$ and $K_{D}[\mathrm{ml} /(\mathrm{mg} \times \mathrm{h})]$ : parameters that correlate Lip production or hydrolysis rate to microbial growth

D.O.: dissolved oxigen

$L:$ total lipid $(\mathrm{mg} / \mathrm{ml})$

Lip: extra-cellular lipase (IU/ml)

$S:$ stearin (substrate fat) $(\mathrm{mg} / \mathrm{ml})$

$X$ : total biomass $(\mathrm{mg} / \mathrm{ml})$

$Y_{X S}:$ biomass yield on substrate fat ( $\mathrm{g}$ formed per $\mathrm{g}$ of fat consumed)

$\mu$ : specific growth rate, $\left(\mathrm{h}^{-1}\right)$

*Corresponding author 
The aim of the present study was to assess the potential of valorisation of a solid industrial derivative of tallow, composed of saturated free-fatty acids ("stearin"), by fermentations carried out by the yeast Yarrowia lipolytica ACA-DC 50109 in order to produce microbial lipid, biomass and extra-cellular lipase. High quantities of biomass were produced (biomass yield of around 1.1 $\pm 0.1 \mathrm{~g}$ of total biomass produced per $\mathrm{g}$ of fat consumed) when the organism was grown in shake flasks, regardless of the concentration of extra-cellular nitrogen present. Cellular lipids accumulated in notable quantities regardless of the nitrogen availability of the medium, though this process was clearly favoured at high initial fat and low initial nitrogen concentrations. The maximum quantity of fat produced was $7.9 \mathrm{mg} / \mathrm{ml}$ corresponding to $52.0 \%$ (wt/wt) of lipid in the dry biomass. Lipase production was critically affected by the medium composition and its concentration clearly increased with increasing concentrations of fat and extra-cellular nitrogen concentration reaching a maximum level of $2.50 \mathrm{IU} / \mathrm{ml}$. Lipase concentration decreased in the stationary growth phase. In bioreactor trials, in which higher agitation and aeration conditions were employed compared with the equivalent trial in the flasks, significantly higher quantities of biomass were produced (maximum concentration $30.5 \mathrm{mg} / \mathrm{ml}$, yield of $1.6 \mathrm{~g}$ of total biomass produced per $\mathrm{g}$ of fat consumed) while remarkably lower quantities of cellular lipids and extra-cellular lipase were synthesised. Numerical models successfully simulated both conversion of substrate fat into biomass and production and subsequent hydrolysis of extra-cellular lipase and presented a satisfactory predictive ability verifying the potential for single-cell protein and lipase production by Yarrowia lipolytica ACA-DC 50109. In all cultures, the mycelial form of the culture was dominant with few single cells present.

Current agricultural and industrial practice has led to an enormous generation of various low- or negative-cost crude fatty materials difficult to treat and valorise (e.g. tallow, waste-fats, soapstocks, rapeseed oil, grease-containing waste-waters, etc.) (Fickers et al. 2005a). Besides issues provided by the use of these substances as starting materials for bio-diesel production, biotechnological applications of fatty materials aiming at the synthesis of high-added value metabolites (e.g. single-cell protein, microbial lipids, organic acids, bio-surfactants, lipases) are of great economical and ecological significance (Adamczak and Bednarski, 1996; Čertik et al. 1997; Adamczak and Bednarski, 2000; Papanikolaou et al. 2001; Oswal et al. 2002; Papanikolaou and Aggelis, 2003; Fickers et al. 2004; Fickers et al. 2005a; Fickers et al. 2005b; Mantzouridou et al. 2006; Szczęsna-Antczak et al. 2006). Amongst fatty materials, widely available low-added ones are various animal fats and tallow or their industrial derivatives, which, while underused nowadays due to their replacement by vegetable oils, could become a competitive substrate for various microbial transformations. Nevertheless, few investigations dealing with the biotechnological valorisation of these low added-value materials have been conducted so far in the literature and are mainly referred to the production of sophorolipids, citric acid and enzymes by yeasts or moulds (Bednarski et al. 1994; Adamczak and Bednarski, 1996; Adamczak and Bednarski, 2000; Kamzolova et al. 2005).

The non-conventional dimorphic yeast Yarrowia (CandidaSaccharomycopsis) lipolytica has been efficiently cultivated on various hydrophobic substances producing many extra- or intra-cellular metabolites of industrial significance (Fickers et al. 2005a; Finogenova et al. 2005). Traditionally, the most widespread biotechnological application of strains belonging to this species has focused on the production of single-cell protein (microbial biomass) (Barth and Gaillardin, 1996; Musiał et al. 2004). In spite of the fact that species of the yeast $Y$. lipolytica were considered as good candidates for single-cell oil or lipase production (Hadeball, 1991; Ratledge, 1994), the production of these metabolites by $Y$. lipolytica strains has only recently been studied in detail. Wild or genetically engineered strains have recently been reported capable of storing huge quantities of intra-cellular lipid, located in lipid bodies, during growth on various hydrophobic materials (Papanikolaou et al. 2001; Papanikolaou and Aggelis, 2003; Mličková et al. 2004). The storage lipid was mainly composed of neutral fractions, i.e. triacylglycerols and to a lesser extent free-fatty acids and steryl-esters (Papanikolaou et al. 2001; Athenstaedt et al. 2006). Various studies have indicated that in $Y$. lipolytica strains, cellbound or extra-cellular lipase production is stimulated by the presence into the culture medium of long-chain fatty acids, triacylglycerols and organic nitrogen (e.g. urea, peptone or yeast extract) (Adamczak and Bednarski, 1996; Pereira-Meirelles et al. 1997; Pereira-Meirelles et al. 2000; Dominguez et al. 2003; Fickers et al. 2004; Fickers et al. 2005a; Fickers et al. 2005b). Lipase production is also critically affected by the presence of surfactants and the aeration and the agitation of the culture medium, and with wild $Y$. lipolytica strains, quantities ranging from 1.0 up to $58.5 \mathrm{IU} / \mathrm{ml}$ ( $1 \mathrm{IU}$ defined as the quantity of the enzyme required for the liberation of $1 \mu \mathrm{mol}$ of fatty acid per min) have been achieved (Dominguez et al. 2003; Alonso et al. 2005; Kamzolova et al. 2005). Additionally, genetic engineering or mutagenesis have been employed in order to improve lipase production, and after extensive selection of new over-producing genetically engineered derivatives and optimisation of culture conditions, the concentrations have been remarkably ameliorated (Nicaud et al. 2002; Fickers et al. 2004; Fickers et al. 2005b).

In recent investigations, $Y$. lipolytica strain ACA-DC 50109 has been cultivated on industrial free fatty acids and 
Table 1. Optimised and experimental parameter values during batch bioreactor culture of Yarrowia lipolytica on stearin. Culture conditions: $S_{0}=20 \mathrm{mg} / \mathrm{ml}, \mathrm{pH}=6.0$, incubation temperature $\mathrm{T}=28^{\circ} \mathrm{C}$, fat $/\left(\mathrm{NH}_{4}\right)_{2} \mathrm{SO}_{4}$ ratio $20 \mathrm{~g} / \mathrm{g}$, agitation rate $650 \pm 20 \mathrm{rpm}$, aeration rate 0.3 v.v.m., oxygen saturation $60-70 \%(v / v)$ for all growth phases. Kinetics conducted in duplicate by using different inocula.

\begin{tabular}{|c|c|c|c|}
\hline & Verhlust & Blackman-Williams & $\begin{array}{l}\text { Experimental } \\
\text { values }\end{array}$ \\
\hline$\mu_{\max }\left(\mathrm{h}^{-1}\right)$ & 0.057 & 0.052 & 0.17 \\
\hline$Y_{X / S}(g / g)$ & 1.38 & 1.25 & 1.56 \\
\hline$X_{\max }(\mathrm{mg} / \mathrm{ml})$ & 27.19 & - & 30.5 \\
\hline a (IU/mg) & $3.93 \times 10^{-3}$ & $4.09 \times 10^{-3}$ & n.d. ${ }^{\S}$ \\
\hline$K_{D}[\mathrm{ml} /(\mathrm{mg} \times \mathrm{h})]$ & $3.93 \times 10^{-4}$ & $3.63 \times 10^{-4}$ & n.d. ${ }^{\S}$ \\
\hline$x^{2}$ & 189 & 232 & - \\
\hline$x^{2} / \mathrm{D} . \mathrm{F}$ & 4.72 & 5.65 & - \\
\hline
\end{tabular}

produced notable quantities of reserve lipid that presented a composition similar to that of cocoa-butter (Papanikolaou et al. 2001). The present investigation aims to use this organism to valorise an industrial derivative of tallow, generated in abundant quantities, in order to produce microbial lipid (single-cell oil), lipases and microbial biomass (single-cell protein). Bio-kinetic interpretations of the experimental data are considered and discussed.

\section{MATERIALS AND METHODS}

\section{Microorganism, media and culture conditions}

Y. lipolytica was isolated and identified in the Laboratory of General and Agricultural Microbiology - Agricultural University of Athens and obtained the code LGAM S(7)1. Then the strain was deposited in the Greek Coordinated Collections of Microorganisms obtaining the official reference number ACA-DC 50109. The microorganism was maintained on potato dextrose agar (Fluka) at $\mathrm{T}=5 \pm 1{ }^{\circ} \mathrm{C}$. The salt composition of the medium has been described in previous investigations (Papanikolaou et al. 2001). Nitrogen sources used were $\left(\mathrm{NH}_{4}\right)_{2} \mathrm{SO}_{4}$ (Fluka) (at various concentrations as indicated in the text) and yeast extract (Fluka) (at $2.0 \mathrm{mg} / \mathrm{ml}$ ). The initial medium $\mathrm{pH}$ was $6.0 \pm$ 0.1 . Stearin [an industrial solid fat composed of $100 \%$ (wt/wt) free-fatty acids] purchased by the Hellenic Chemical Industry PAPOUTSANIS A.S., was used as the sole carbon source. The fatty acid composition of stearin was as follows (\%,wt/wt): C12:0 10; C14:0 10; C16:0 25; C18:0 52; ${ }^{\Delta 9} \mathrm{C} 18: 12 ;{ }^{\Delta 9}{ }^{12} \mathrm{C} 18: 2<0.5$. Tween 80 (Fluka) and PEG 20000 (Fluka) at 10\% (wt/wt fat) of each were added as emulsifiers. An Ultra Turrax homogeniser (T25 basic) (Janke and Kunkel, Germany) allowed the dispersion of fat particles into the aqueous phase.

All experiments were performed in batch mode. Cultures were done in either $250 \mathrm{ml}$ conical flasks or a 21 roundbottom bioreactor (Applikon, The Netherlands). In the case of cultivation in $250 \mathrm{ml}$ flasks, flasks containing $50 \pm 1 \mathrm{ml}$ of growth medium were inoculated with $1 \mathrm{ml}$ of exponential preculture (preculture carried out in the synthetic medium with stearin at $10 \mathrm{mg} / \mathrm{ml}$ and $\left(\mathrm{NH}_{4}\right)_{2} \mathrm{SO}_{4}$ at $0.5 \mathrm{mg} / \mathrm{ml}$ ) which contained $1-3 \times 10^{6}$ cells. Flasks were incubated in an orbital shaker (New Brunswick Scientific, U.S.A.) at an agitation rate of $180 \pm 5 \mathrm{rpm}$. In flask cultures, the effect of initial stearin and $\left(\mathrm{NH}_{4}\right)_{2} \mathrm{SO}_{4}$ concentration upon growth was investigated. Trials with stearin at two initial concentrations, 10 and $20 \mathrm{mg} / \mathrm{ml}$ and $\left(\mathrm{NH}_{4}\right)_{2} \mathrm{SO}_{4}$ at concentrations ranging from 0 to $10 \mathrm{mg} / \mathrm{ml}$ were carried out.

In the bioreactor experiments, the fermentor with an initial fermentation volume 1.551 , was inoculated with 0.051 of a $24 \mathrm{hrs}$ pre-culture (the same pre-culture as in flask trials), the agitation rate was $650 \pm 20 \mathrm{rpm}$ and the aeration rate was adjusted to 0.3 v.v.m. The stearin $/\left(\mathrm{NH}_{4}\right)_{2} \mathrm{SO}_{4}$ ratio used was $20 \mathrm{~g} / \mathrm{g}$ while the initial stearin concentration was $20 \mathrm{mg} / \mathrm{ml}$. Silicone (Sigma) was periodically added as an antifoam agent. In order to avoid excessive foaming, specifically in the bioreactor trials, sterile air was also added in some cases from the upper part of the reactor. In all experiments (flask or bioreactor trials), the incubation temperature was $\mathrm{T}=28 \pm 1^{\circ} \mathrm{C}$.

\section{Analytical methods}

In flask experiments, dissolved oxygen (D.O.) was determined off-line with the aid of a selective electrode (oxi200 Sensodirect, Lovinbod). Before harvesting, the shaker was stopped and the probe was placed into the flask. Then, the shaker was switched on and the measurement was taken after D.O. equilibration (usually within $10 \mathrm{~min}$ ). $\mathrm{pH}$ was measured using a Jenway $3020 \mathrm{pH}$-meter. In the bioreactor cultures, $\mathrm{pH}$ was adjusted to $6.0 \pm 0.1$ and was automatically controlled by addition of $1 \mathrm{M} \mathrm{NaOH}$, while the levels of dissolved oxygen were determined on-line by a selective electrode (Adi 1020, Applikon).

Cells were harvested by centrifugation (Heraeus Sepatech Suprafuge-22 apparatus) at $7000 \mathrm{xg} / 20 \mathrm{~min}$ and washed successively with ethanol and hexane (Papanikolaou et al. 2001). Biomass concentration was determined from the dry weight (drying at $85 \pm 5^{\circ} \mathrm{C}$ until constant weight). 


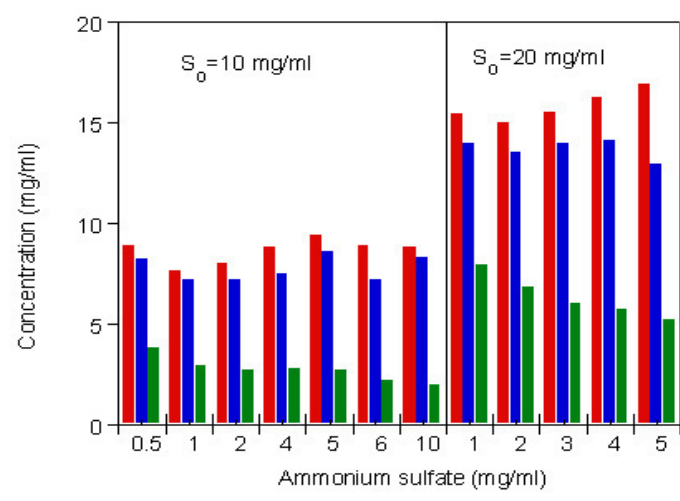

- X $(\mathrm{mg} / \mathrm{ml})$ - S consumed $(\mathrm{mg} / \mathrm{ml})=\mathrm{L}(\mathrm{mg} / \mathrm{ml})$

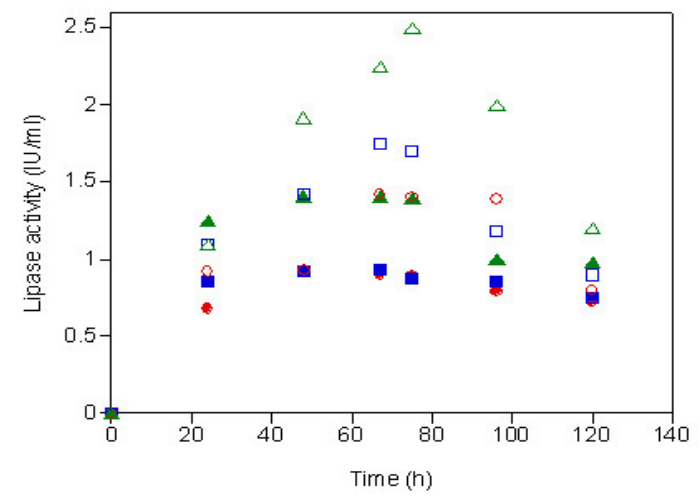

- $\mathrm{S}_{0} 10 \mathrm{mg} / \mathrm{ml},\left(\mathrm{NH}_{4}\right)_{2} \mathrm{SO}_{4} 0.5 \mathrm{mg} / \mathrm{ml}$ $\square \quad \square \mathrm{S}_{0} 10 \mathrm{mg} / \mathrm{ml},\left(\mathrm{NH}_{4}\right)_{2} \mathrm{SO}_{4} 4.0 \mathrm{mg} / \mathrm{ml}$

Figure 1. Kinetics of Yarrowia lipolytica growth on stearin used as the sole carbon source in flask experiments. Representation of biomass produced $(X, \mathrm{mg} / \mathrm{ml})$, substrate fat consumed $(S, \mathrm{mg} / \mathrm{ml})$ and lipid produced $(L, \mathrm{mg} / \mathrm{ml})$ when maximum concentration of cellular lipids was observed (a) and evolution of lipase produced with time (b) during growth of Yarrowia lipolytica at initial stearin concentration 10 or 20 $\mathrm{mg} / \mathrm{ml}$ and variations in the initial concentration of $\left(\mathrm{NH}_{4}\right)_{2} \mathrm{SO}_{4}$. Culture conditions: growth on flasks, $\mathrm{T}=28 \pm 1^{\circ} \mathrm{C}$, agitation rate $180 \pm 5 \mathrm{rpm}, S_{0}=10$ or $20 \mathrm{mg} / \mathrm{ml}$. Kinetics conducted in at least duplicate by using different inocula.

Unconsumed substrate fat was extracted twice using petroleum ether and chloroform as extracting solvents. The solvents were removed with the aid of a flash evaporator and the remaining fat was gravimetrically measured. Total cellular lipid was extracted from dry biomass with a mixture of chloroform and methanol 2:1 (v/v). Solvents were removed at reduced pressure and lipid was determined gravimetrically. Cellular or unconsumed lipids were converted to methyl-esters in a two step reaction with methanolic sodium and hydrochloric methanol and analysed in a Fisons 8000 series G.L.C. as previously described (Papanikolaou et al. 2001). Lipase activity was measured by a titrimetric assay, according to the protocol described by Kamzolova et al. (2005). An emulsion created by olive oil at $40 \%(\mathrm{v} / \mathrm{v})$ and polyvinyl alcohol (Fluka) at $2 \%(\mathrm{wt} / \mathrm{v})$ was used as substrate for the lipase assay. The solution was emulsified with the aid of an Ultra Turrax homogeniser (Janke and Kunkel) in order to obtain a satisfactory dispersion of oil particles into the aqueous phase. The assay sample $(500 \mu \mathrm{l})$ containing culture medium and cells was added to the substrate emulsion (5.0 $\mathrm{ml})$ and $0.05 \mathrm{M}$ phosphate buffer $(4.5 \mathrm{ml})$. The whole mixture $(10.0 \mathrm{ml})$ was incubated for $1 \mathrm{hr}$ on a shaker (New Brunswick Scientific) at an agitation rate of $180 \pm 5 \mathrm{rpm}$ at $\mathrm{T}=28 \pm 1^{\circ} \mathrm{C}$. The effect of $\mathrm{pH}$ upon the lipase activity was studied at a broad range of $\mathrm{pH}$ (from 5.0 to 8.5), and the optimal $\mathrm{pH}$ value in order to proceed with the lipase assay was found to be that of 8.0 (in accordance with the findings of Kamzolova et al. 2005). In order to investigate if produced lipase was extra-cellular or cell-bound, the assay sample $(500 \mu \mathrm{l})$ was filtered through a $0.20 \mu \mathrm{m}$ filter (elimination of microbial cells and assay, hence, of extracellular lipase), and it was found that lipase produced was almost completely extra-cellular.

\section{Microscopic observations}

In all trials, yeast morphology was checked by light microscopic observations made by a Zeiss (Axioscop 40, Germany) microscope. Photographed cells were stained with crystal violet and viewed at x 100 .

\section{RESULTS}

\section{Growth in flasks}

In the first part of the investigation, the effects of nitrogen and substrate fat availability upon microbial growth, lipid accumulation and lipase secretion were studied. In this series of experiments, the initial concentration of stearin, $S_{0}$, was first adjusted to $10 \mathrm{mg} / \mathrm{ml}$ and the concentration of $\left(\mathrm{NH}_{4}\right)_{2} \mathrm{SO}_{4}$ ranged from 0.5 to $10.0 \mathrm{mg} / \mathrm{ml}$ (kinetics carried out with $0.5,1.0,2.0,4.0,5.0,6.0$ and $10.0 \mathrm{mg} / \mathrm{ml}$ ). In all of the cultures and regardless of the extra-cellular nitrogen availability of the medium, significant biomass and lipid quantities were produced $\left(X_{\max }=8.0 \pm 0.5 \mathrm{mg} / \mathrm{ml}, L_{\max }=\right.$ $3.9 \pm 0.5 \mathrm{mg} / \mathrm{ml}$ ) (Figure 1a). Fat was removed from the culture medium with comparable rates regardless of the available nitrogen quantity in the medium (kinetics not presented). Total cellular lipid was produced in significant quantities regardless of the nitrogen availability into the medium [lipid from 25 to $44 \%$ (wt/wt) in dry weight] with the higher quantities produced when low initial nitrogen media were employed, while at the stationary growth phase significant quantities of substrate fat remained unconsumed [around $25 \pm 6 \%(\mathrm{wt} / \mathrm{wt}$ ) of the initial fat quantity] (see cases with $S_{0}=10 \mathrm{mg} / \mathrm{ml}$ in Figure 1a). To further investigate the effect of nitrogen availability of the medium upon microbial growth experiments, an initial stearin concentration $S_{0}=20 \mathrm{mg} / \mathrm{ml}$ and $\left(\mathrm{NH}_{4}\right)_{2} \mathrm{SO}_{4}$ concentrations 1.0, 2.0, 3.0, 4.0 and $5.0 \mathrm{mg} / \mathrm{ml}$ were used. $X_{\max }$ and $L_{\max }$ 
values significantly increased despite variations in the nitrogen concentration in the medium $(X=16.0 \pm 0.9$ $\mathrm{mg} / \mathrm{ml}, L=7.1 \pm 0.8 \mathrm{mg} / \mathrm{ml}$ ) while, as in the previous trials lipid production was favoured at low nitrogen concentration media (see cases with $S_{0}=20 \mathrm{mg} / \mathrm{ml}$ in Figure 1a). Significant quantities of extra-cellular substrate fat, higher than in the trials with $S_{0}=10 \mathrm{mg} / \mathrm{ml}$, remained unconsumed in the medium at the end of the fermentation $\left[\mathrm{S}_{\mathrm{r}}=6.5 \pm 0.5\right.$ $\mathrm{mg} / \mathrm{ml}$ corresponding to around $32 \pm 4 \%$ (wt/wt) of the initial fat quantity] (Figure 1a). The highest amount of cellular lipid produced was $7.9 \mathrm{mg} / \mathrm{ml}$ [corresponding to $52.0 \%$ (wt/wt) in dry weight] and was observed in the culture with the ratio $(S) /\left(\mathrm{NH}_{4}\right)_{2} \mathrm{SO}_{4} 10 / 0.5 \mathrm{~g} / \mathrm{g}(=20 / 1.0$ $\mathrm{g} / \mathrm{g}$ ), while in all cases and regardless of substrate fat or $\left(\mathrm{NH}_{4}\right)_{2} \mathrm{SO}_{4}$ concentration in the medium, the yield $Y_{X / S}$ presented remarkable values of $1.10 \pm 0.10 \mathrm{~g} / \mathrm{g}$.

Extra-cellular lipase was produced regardless of the substrate fat or the nitrogen concentration in the medium, and occurred during primary anabolic activity. Enzyme production was clearly enhanced with increases in $\left(\mathrm{NH}_{4}\right)_{2} \mathrm{SO}_{4}$ and $S$ concentrations (Figure 1b); when $S_{0}=10$ $\mathrm{mg} / \mathrm{ml}$, the Lip $\max _{\max }$ value obtained was $1.41 \mathrm{IU} / \mathrm{ml}$ in the medium with $\left(\mathrm{NH}_{4}\right)_{2} \mathrm{SO}_{4}$ at $10 \mathrm{mg} / \mathrm{ml}$ while the respective value when the initial $\left(\mathrm{NH}_{4}\right)_{2} \mathrm{SO}_{4}$ quantity was adjusted to $0.5 \mathrm{mg} / \mathrm{ml}$ was $0.88 \mathrm{IU} / \mathrm{ml}$ (Figure 1b). Increases in both substrate fat and $\left(\mathrm{NH}_{4}\right)_{2} \mathrm{SO}_{4}$ concentrations significantly increased the concentration of produced lipase, with the Lip $_{\max }$ value $2.50 \mathrm{IU} / \mathrm{ml}$ obtained when $S_{0}=20 \mathrm{mg} / \mathrm{ml}$ and the initial $\left(\mathrm{NH}_{4}\right)_{2} \mathrm{SO}_{4}$ concentration was $5.0 \mathrm{mg} / \mathrm{ml}$ (Figure 1b). In all cultures and regardless of the initial fat or $\left(\mathrm{NH}_{4}\right)_{2} \mathrm{SO}_{4}$ concentration in the culture medium, lipase concentration decreased during the stationary growth phase (Figure 1b).

D.O. concentrations of the growth medium in the flask fermentations ranged in values between 20 and $60 \%(\mathrm{v} / \mathrm{v})$ of the saturation for the period 0-100 hrs after inoculation, before increasing to values higher than $65 \%$ at the end of fermentation (after $100 \mathrm{hrs}$ ), indicating that full aerated conditions were employed. It is also noted that in spite of the fact that some of the trials were conducted in nitrogenlimited conditions [e.g. $S_{0}=20 \mathrm{mg} / \mathrm{ml},\left(\mathrm{NH}_{4}\right)_{2} \mathrm{SO}_{4} 1.0$ $\mathrm{mg} / \mathrm{ml}$ ], the $\mathrm{pH}$ of the medium dropped very little ( $\mathrm{pH}$ drop of the medium around $0.5 \pm 0.1$ units). Low quantities of organic acids were produced (total amount of organic acids up to $1.4 \pm 0.3 \mathrm{~g} / \mathrm{l}$, main organic acids detected by H.P.L.C. analysis were acetic and citric acid).

\section{Growth in a bioreactor}

Given that the higher quantity of cellular lipid was produced in the medium containing initial stearin $\left(S_{0}\right)$ at 20 $\mathrm{mg} / \mathrm{ml}$ and $(S) /\left(\mathrm{NH}_{4}\right)_{2} \mathrm{SO}_{4}$ ratio $20 \mathrm{~g} / \mathrm{g}$, growth was carried out in a bioreactor experiment with these culture conditions. The culture $\mathrm{pH}$ was adjusted and maintained at the value of $6.0 \pm 0.1$, and a higher agitation rate, than that used in the shake flask studies, was employed (650 against $180 \mathrm{rpm})$. The oxygenation in the culture medium was higher compared with the 250-ml flask culture experiments; in the period $0-140 \mathrm{hrs}$ after inoculation the D.O. ranged between 45 and $70 \%(\mathrm{v} / \mathrm{v})$ of the saturation level. Higher agitation and oxygenation rates seemed to critically influence the metabolism of $Y$. lipolytica; significantly higher quantities of biomass $\left(X_{\max }=30.5 \mathrm{mg} / \mathrm{ml}\right)$ and lower quantities of total lipid $[L=2.5-4.0 \mathrm{mg} / \mathrm{mlcorresponding} \mathrm{to}$ $7-16 \%(\mathrm{wt} / \mathrm{wt})$ of lipid in dry weight] were produced compared with the respective fermentation carried out in 250-ml flasks. Likewise, in the bioreactor experiment, extra-cellular lipase activity was remarkably lower compared with the equivalent flask trial (maximum activity 0.95 against $1.42 \mathrm{IU} / \mathrm{ml}$ ). These differences were attributed to the different aeration and agitation conditions between the $250-\mathrm{ml}$ flask and the bioreactor culture.

A numerical model capable of quantifying the production of biomass and the biosynthesis and subsequent degradation of lipase by $Y$. lipolytica cultivated on stearin in the bioreactor trial was developed. The equations of the model are presented below:

- Substrate fat consumption rate: $-\frac{d S}{d t}=\mu \cdot X \cdot \frac{1}{Y_{X / S}}[1]$

- Biomass production rate: $\frac{d X}{d t}=\mu \cdot X$

- Lipase synthesis rate: $\frac{d \operatorname{Lip}}{d t}=a \cdot \mu \cdot X-K_{D} \cdot \operatorname{Lip} \cdot X$

From the above equation it can be assumed that Lip activity was considered as a primary anabolic activity, while its hydrolysis rate was considered to be quantitatively related to the biomass concentration $(X)$ in the growth medium (proteases were considered as cell-bounded enzymes).

- The specific growth rate $(\mu)$ was expressed by two equations:

$\mu=\mu_{\max } \cdot\left(1-\frac{X}{X_{\max }}\right) \quad$ [4] (Verhlust type equation) or

$\mu=\mu_{\max } \cdot\left(\frac{S}{S_{0}}\right)$ [5] (Blackman-Williams type equation, modified according to Galiotou-Panayotou et al. (1998)).

It can be deduced, hence, that $\mu$ was either governed by the maximum attainable culture density $\left(X_{\max }\right.$-carrying capacity of the system), or it linearly decreased with the diminution of the available quantity of substrate fat used as the sole carbon source. 

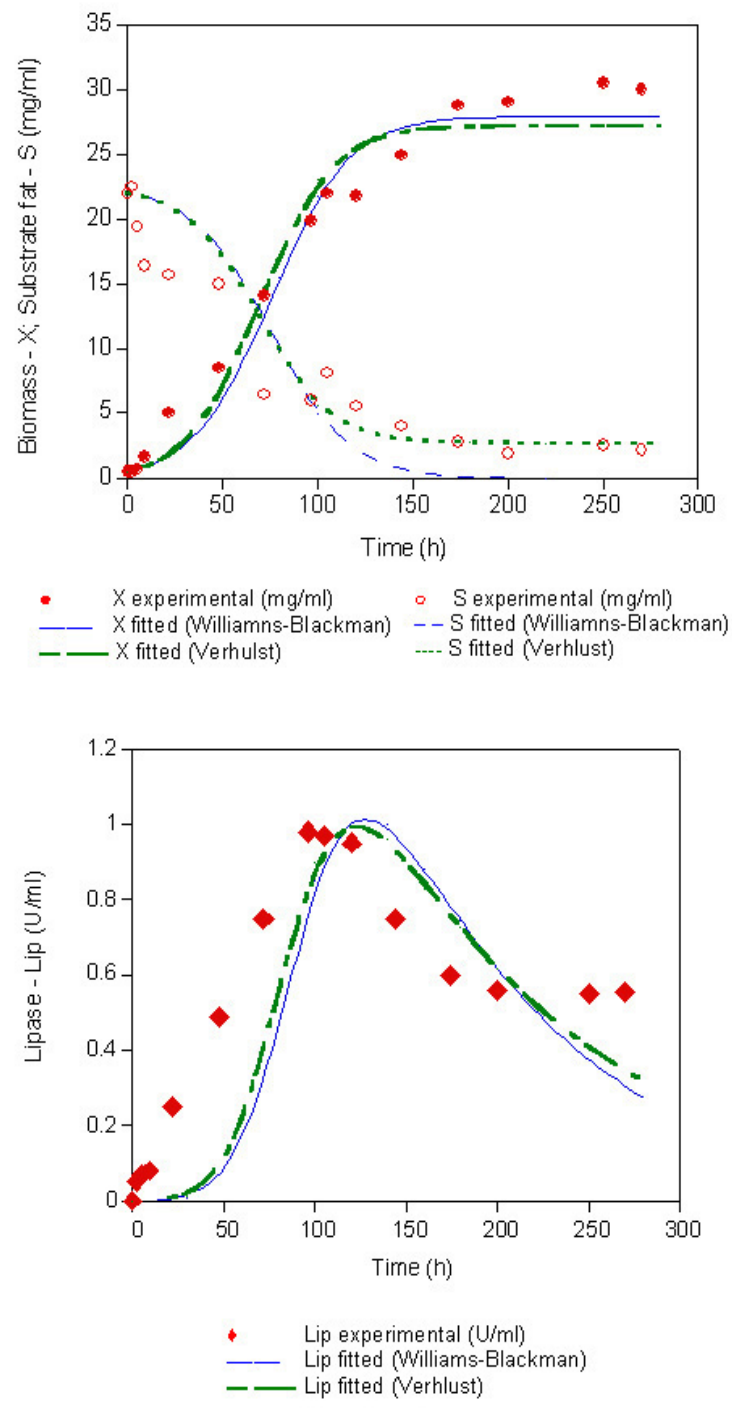

Figure 2. Biomass $(X, \mathrm{mg} / \mathrm{ml})$, substrate fat $(\mathrm{s}, \mathrm{mg} / \mathrm{ml})(\mathrm{a})$ and extra-cellular lipase (Lip, IU/ml) (b) evolution during growth of Yarrowia lipolytica in batch bioreactor experiment. Representation of experimental points and theoretical curves of application of Verhlust- or BlackmanWilliams-type numerical models. Culture conditions: growth on bioreactor, $\mathrm{T}=28 \pm 1^{\circ} \mathrm{C}$, stearin $/\left(\mathrm{NH}_{4}\right)_{2} \mathrm{SO}_{4} 20 \mathrm{~g} / \mathrm{g}, S_{0}=20$ $\mathrm{mg} / \mathrm{ml}, \mathrm{pH}=6.0 \pm 0.1$, agitation rate $650 \pm 20 \mathrm{rpm}$, aeration rate 0.3 v.v.m.. Kinetics conducted in duplicate by using different inocula.

Differential equations were integrated by using the RungeKutta $4^{\text {th }}$ order integration method, while the parameters for optimisation were maximum specific growth rate $\left(\mu_{\max }\right)$, maximum biomass achieved $\left(X_{\max }\right)$, biomass yield on fat consumed $\left(Y_{X / S}\right), \alpha$ (parameter related with the production of lipase as primary anabolic product) and $K_{D}$ (parameter related with the degradation of lipase). The parameters were optimised using the least squares method, while the Marquardt iterative search algorithm (initial $\lambda=10^{-3}$ ) was used to determine the parameter values that minimised the

residual sum of squares. Both models fitted well on the experimental data (Figure 2a and Figure 2b) while comparison between the optimised-predicted parameter values and those experimentally measured were satisfactory, indicating the validity of the proposed models (Table 1). If various constraints were imposed (e.g. change of the initial values of the parameters), the models converged always towards the optimised parameter values. Furthermore, attempt to introduce the term of the energy of maintenance coefficient $\left(m_{S}\right)$ in Equation [1] was not successful given that during optimisation process $m_{S}$ tended to achieve almost negligible values [e.g. values of around $\left.1.2 \times 10^{-12} \mathrm{~g} /(\mathrm{g} \times \mathrm{h})\right]$.

\section{Lipid analysis and strain morphology}

Yeast morphology and fatty acid composition of cellular and extra-cellular fat were studied during all of the experimental runs. In all trials and despite variations in the quantity of fat or nitrogen utilised in the culture medium or the mode of culture (cultivation in either flasks or bioreactor), $Y$. lipolytica was present primarily in its mycelial form with few single cells observed. True mycelium development was observed even at the very early stages of fermentation and this morphology was maintained until the end of the culture (up to 250-300 hrs after inoculation). A characteristic photographic picture of the morphology of $Y$. lipolytica cultivated on stearin is shown in Figure 3.

In all trials and regardless of the nitrogen availability and the agitation and aeration rate employed, the remaining fat was notably richer in C18:0 (around 75\% (wt/wt) of total lipid) and less rich in C12:0, C14:0 and C16:0 compared with the initial composition of the fatty mixture. Also, the microorganism had the tendency to produce a highly saturated cellular lipid; cellular C18:0 presented the value of $78 \pm 3 \%$, wt $/ \mathrm{wt}$, of total lipids. C16:0 presented the value of $17 \pm 2 \%$, wt/wt, of total lipids, while cellular ${ }^{\Delta 9} \mathrm{C} 18: 1$ was produced in quite small quantities $(5 \pm 2 \%$, wt/wt, of total cellular lipids). It was noted that higher quantities of oleic acid were obtained in the highly aerated bioreactor experiment, in which lipid accumulation was not dominant (cellular ${ }^{{ }^{9}} \mathrm{C} 18: 1$ around $6-7 \%(\mathrm{wt} / \mathrm{wt})$ in the bioreactor trial against $2.0-3.5 \%(\mathrm{wt} / \mathrm{wt})$ in flask trials).

\section{Repeatability and statistical analysis}

In order to validate the experimental findings, all of the experiments were done at least in duplicate. Furthermore, an additional experiment was conducted, in which a flask culture of $Y$. lipolytica was carried out at $S_{0}=10 \mathrm{mg} / \mathrm{ml}$ and initial $\left(\mathrm{NH}_{4}\right)_{2} \mathrm{SO}_{4} 0.5 \mathrm{mg} / \mathrm{ml}$. Flasks were simultaneously collected $72 \mathrm{hrs}$ after inoculation, assay of extra-cellular lipase was carried out while biomass from each flask was collected and dried and microbial lipid was extracted. Also residual substrate fat was extracted from the culture medium. The obtained result for 8 individual flasks showed the following feature: for total biomass $(X)$ maximum and 
minimum values were 7.0 and $7.8 \mathrm{mg} / \mathrm{ml}$ respectively, with a mean value of $7.40 \mathrm{mg} / \mathrm{ml}$, an obtained standard deviation of 0.269 , a standard error of 0.101 and a variance of 0.072 . For microbial lipid $(L)$, maximum and minimum values were 3.1 and $2.5 \mathrm{mg} / \mathrm{ml}$, respectively, with a mean value of $2.84 \mathrm{mg} / \mathrm{ml}$, a standard deviation of 0.222 , a standard error of 0.08 and a variance of 0.049 . For residual fat $\left(S_{r}\right)$, maximum and minimum values were 1.8 and $2.5 \mathrm{mg} / \mathrm{ml}$ respectively, with a mean value of $2.08 \mathrm{mg} / \mathrm{ml}$, an obtained standard deviation of 0.195 , a standard error of 0.074 and a variance of 0.038 . Finally, for the secreted lipase (Lip) maximum and minimum values were 0.91 and $0.82 \mathrm{IU} / \mathrm{ml}$ respectively, with a mean value of $0.86 \mathrm{IU} / \mathrm{ml}$, an obtained standard deviation of 0.039 , a standard error of 0.015 and a variance of 0.002 . These findings indicated satisfactory repeatability of the experiments.

\section{DISCUSSION}

$Y$. lipolytica was cultivated on an inexpensive solid and saturated industrial derivative of tallow, as the sole carbon source, and presented impressive cell growth. Despite the physico-chemical characteristics of the substrate fat (solid in ambient temperature), this substrate was rapidly removed from the cultivation medium. However, significant quantities of fat remained unconsumed at the stationary growth phase, regardless of the initial fat or nitrogen concentration in the growth medium or the culture configuration (growth on bioreactor or flasks). Tan and Gill (1985) considered that yeast strains did not grow sufficiently well on solid fats due to inadequate dispersion of these substrates into the liquid medium. While liquid fats are dispersed with moderate agitation, solid fats require considerable agitation (e.g. $1200 \mathrm{rpm}$ ) for dispersal in the growth medium. Similarly, cultivation of yeasts and fungi (strains belonging to $Y$. lipolytica, Mucor miehei and Geotrichum candidum) on animal-waste fats for relatively long fermentation times resulted in limited fat removal from the growth medium, while the more the fat was saturated (and hence solid) the more the quantity of remaining substrate was high at the end of fermentation. For instance, fermentations carried out by various $Y$. lipolytica strains resulted in removal of $18 \pm 4 \%$ (wt/wt) of beef tallow while the respective values for poultry fat was $36 \pm 4 \%$ (wt/wt) (Bednarski et al. 1994). However, in at least one case, cultivation of a newly isolated $Y$. lipolytica strain on beef tallow, resulted in fat removal of $75 \%$ (wt/wt) at optimum fermentation conditions (fat removal values near to our study) (Davin and Quilty, 2001). In contrast, cultivation of various moulds resulted in almost complete lipid removal $[95 \pm 5 \%$ (wt/wt) of the initial fat quantity] when growth was carried out on liquid fats (Čertik et al. 1997; De Felice et al. 1997; Mantzouridou et al. 2006; Szczęsna-Antczak et al. 2006). In general, limited substrate removal on solid fats, is not only due to the physico-chemical condition of the substrate but also to the biochemical composition of the substrate. The selective uptake of fatty acids by $Y$. lipolytica has preciously been reported (Papanikolaou et al. 2001; Papanikolaou and
Aggelis, 2003). In general, Y. lipolytica strains cultivated on fatty materials tended to metabolise the poly-unsaturated fatty acids and to accumulate the mono-unsaturated and saturated ones (Aggelis et al. 1997; Kamzolova et al. 2005). Likewise, other yeast strains (e.g. S. lipolytica ATCC 8661 and Apiotrichum curvatum ATCC 20509) presented restricted growth when cultivated on media rich in C18:0 (Tan and Gill, 1985; Lee et al. 1993).

Y. lipolytica cultivated on saturated free-fatty acids produced some quantities of extra-cellular lipase. The simultaneous production of microbial lipid and lipase has rarely been reported (Szczęsna-Antczak et al. 2006). A wide range of microorganisms has been reported capable of producing lipases with different enzymological properties and substrate specificities (Hadeball, 1991; Dalmau et al. 2000; Sharma et al. 2001; Montesinos et al. 2003; Szczęsna-Antczak et al. 2006). Among them, various $Y$. lipolytica strains have been tested, with secretion of extracellular lipase being stimulated by the presence of longchain fatty acids or triacylglycerols as carbon source and organic nitrogen (i.e. urea, peptone, yeast extract) as nitrogen source in the growth medium (Fickers et al. 2004; Fickers et al. 2005a; Fickers et al. 2005b). In the present study, the simultaneous increase of carbon and nitrogen concentrations notably increased lipase yield $\left(\mathrm{Lip}_{\max }=2.50\right.$ $\mathrm{IU} / \mathrm{ml})$. In accordance with our findings, Montesinos et al. (2003) studying the effect of nitrogen limitation upon lipase secretion by Candida rugosa ATCC found that Lip secretion was almost completely suppressed in nitrogenlimited media. Pereira-Meirelles et al. (1997) reported maximum lipase concentrations around $2.5-3.0 \mathrm{IU} / \mathrm{ml}$ by a wild C. lipolytica strain cultivated on media containing olive oil and peptone, while higher quantities of total

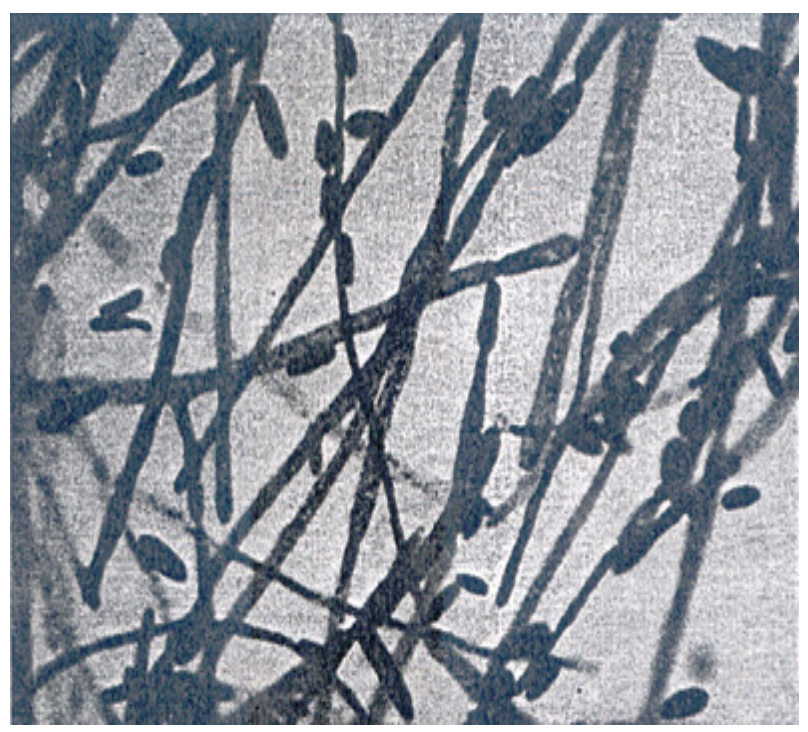

Figure 3. Typical mycelium morphology of Yarrowia lipolytica cultivated on stearin used as the sole carbon source. Magnification x100. 
(extra-cellular and cell-bound) lipase were obtained in media enriched with both yeast extract and peptone (5.0-8.5 $\mathrm{IU} / \mathrm{ml}$ ) (Pereira-Meirelles et al. 2000). Additionally, lipase production was lowered when the agitation rate in the medium increased (Alonso et al. 2005). Kamzolova et al. (2005) screened a huge number of $Y$. lipolytica strains and reported lipase activities ranging from 1.8-45.5 IU/ml. Results for other wild Candida species showed a lipase production of the same magnitude with the present investigation (e.g. concentrations $2-15 \mathrm{IU} / \mathrm{ml}$ for various carbon sources used) (Dalmau et al. 2000; Montesinos et al. 2003). In order to obtain increased lipase production by $Y$. lipolytica strains, combinations of genetic engineering and mutagenesis methods have been employed. An expression system has been developed and strains containing multicopy integration of the expression cassettes carrying the LIP2 gene expressed under the control of the oleic acidinducible $P O X 2$ promoter were obtained, by using ura3 $d 4$ as selection marker gene (Pignede et al. 2000). Optimisation of the growth parameters in fed-batch cultivation resulted in very high lipase $(60000 \mathrm{IU} / \mathrm{ml})$ and biomass $(100 \mathrm{mg} / \mathrm{ml})$ production (Nicaud et al. 2002). Further selection of overproducing derivatives and use of olive oil and tryptone as substrates yielded the considerable activity of $158246 \mathrm{IU} / \mathrm{ml}$ after $80 \mathrm{hrs}$ of culture (Fickers et al. 2005b).

In the present study, growth of $Y$. lipolytica on solid fats was accompanied by a $\mu_{\max }$ value lower compared with those reported in the literature for strains grown on liquid fats (Aggelis et al. 1997; Mličková et al. 2004; Kamzolova et al. 2005). Very satisfactory values of $Y_{X / S}$ were obtained during cultivation in flasks $(1.1 \pm 0.1 \mathrm{~g} / \mathrm{g})$, while in bioreactor trials the respective value was excellent $(1.5 \pm$ $0.1 \mathrm{~g} / \mathrm{g}$ ). The above findings support the potential of the microorganism for the biotechnological valorisation of saturated waste fats and the production of single-cell protein from fatty materials. In the literature, it is suggested that yield $Y_{X / S}$ values of around $0.9 \pm 0.2 \mathrm{~g} / \mathrm{g}$ are very satisfactory for single-cell protein fermentation from fatty substrates (Aggelis et al. 1997; Alonso et al. 2005) with lower $Y_{X / S}$ values (e.g. 0.5-0.7 g/g) obtained for high-lipase producing wild Y. lipolytica strains (Dominguez et al. 2003; Kamzolova et al. 2005). Additionally, cellular lipid production appeared to be critically influenced by the nitrogen quantity, the agitation and the aeration rate of the growth medium. In the flask cultures (that presented lower oxygen saturation) accumulated lipids were produced in some quantities regardless of the nitrogen availability of the medium $(25-52 \%(\mathrm{wt} / \mathrm{wt})$ in dry matter), but this process was clearly favoured in low-nitrogen concentration media. Cells of Y. lipolytica were saturated with fat at high-stearin and low $\left(\mathrm{NH}_{4}\right)_{2} \mathrm{SO}_{4}$ media $\left(L_{\max }=7.9 \mathrm{mg} / \mathrm{ml}\right)$, resulting in the cessation of carbon source assimilation, as indicated by the large amounts of the fat remaining unconsumed in the growth medium. Therefore, the total lipid content of $52.0 \%$ (wt/wt) should be considered as the upper limit of fat accumulation for this strain. In contrast, in the bioreactor trial, in which higher aeration and agitation were observed, total cellular lipids of only $7-16 \%$ (wt/wt) in dry matter were produced, and a metabolic shift favouring the production of lipid-free material was observed (higher $Y_{X / S}$ value compared with flask trials). Degradation of hydrophobic materials in $Y$. lipolytica strains is a multi-step process requiring different enzymatic activities by acylcoenzyme A oxidases (Aox) (Luo et al. 2002; Mličková et al. 2004; Fickers et al. 2005a). Aox3p is specific for short chain acyl-CoAs, Aox $2 \mathrm{p}$ preferentially oxidises long-chain acyl-CoAs while Aox $1 \mathrm{p}$, Aox $4 \mathrm{p}$ and Aox 5p do not appear of being sensitive in the chain length of the aliphatic acyl-CoA chain (Mauersberger et al. 2001; Luo et al. 2002; Fickers et al. 2005a). Presumably at higher aeration and agitation conditions short-chain acyl-CoA oxidases (Aox $3 \mathrm{p}$ and probably Aoxlp, Aox $4 \mathrm{p}$ and Aox $5 \mathrm{p}$ ) show increased activity, the carbon flow consequently is directed towards the synthesis of acetyl-CoA and, hence, towards lipid-free biomass formation instead of that of reserve lipophilic materials.

Y. lipolytica ACA-DC 50109 underwent a morphological transition from single-cell to true mycelial form rapidly after its cultivation on solid fat materials. Development of the microorganism principally under its filamentous form was enhanced by the presence of saturated free-fatty acids and occurred regardless of the initial concentrations of fat or $\left(\mathrm{NH}_{4}\right)_{2} \mathrm{SO}_{4}$ into the medium, or the cultivation in flasks or bioreactor. Given that during growth on stearin used as substrate for the production of total biomass, the accumulation of storage lipid, the removal of substrate aliphatic chains from the medium and the secretion of lipase the organism was critically affected by the culture conditions used (see previous paragraphs), it may be assumed that the response of the organism was not linked with the morphology of the strain but was related only with the supplied carbon source used. The same strain cultured in nitrogen-limited cultures with glucose or industrial glycerol used as individual substrates or co-substrates developed only into its single-cell form while almost no mycelia were observed (Papanikolaou et al. 2002). In contrast, during cultivation on unsaturated free-fatty acids used as substrates, although storage lipid production was not favoured (Papanikolaou et al. 2001), growth with a mycelium morphology was equally enhanced. In a similar manner, Y. lipolytica NCIM 3589 growing on palm-oil mill effluent (a fat-rich residue) considerably decreased C.O.D. and B.O.D. values while a true mycelium morphology occurred, presumably due to morphological transition in response with the presence of fat into the medium (Oswal et al. 2002). In contrast with results obtained in this study, the cultivation of $Y$. lipolytica strains on hydrophobic materials other that fats (e.g. alkanes) favour the development of the microorganism in its yeast form (Zinjarde et al. 1998), while in others reports, cultivation of strains of the 
aforementioned species on hydrophilic materials (e.g. glucose, citric acid etc) mycelium formation was triggered (Perez-Campo and Dominguez, 2001; Ruiz-Herrera and Sentandreu, 2002).

In conclusion, Y. lipolytica ACA-DC 50109 presented efficient cell growth on media containing a solid fat composed of free-fatty acids used as sole carbon source. Fat was efficiently removed from the growth medium, although non-negligible quantities of substrate, rich in stearic acid, remained unconsumed. In flask cultures, considerable quantities of microbial lipids were accumulated inside the yeast cells, while to a lesser extent extra-cellular lipase was also produced. Lipid accumulation was favoured in relatively high carbon excess conditions in contrast with the secretion of lipase. In bioreactor trials lower quantities of cellular lipids and extra-cellular lipase were produced, while biomass, in terms of both final concentration and yield per fat consumed, was produced in significant quantities. All these findings support the potential of waste fatty material utilisation for the production of useful metabolites by $Y$. lipolytica strains.

\section{ACKNOWLEDGMENTS}

Special thanks are addressed to the unknown referees for kindly revising the language of the manuscript.

\section{REFERENCES}

ADAMCZAK, Marek and BEDNARSKI, Wlodzimierz. Some factors affecting lipase production by yeasts and filamentous fungi. Biotechnology Letters, October 1996, vol. 18 , no. 10 , p. 1155-1160.

ADAMCZAK, Marek and BEDNARSKI, Wlodzimierz. Influence of medium composition and aeration on the synthesis of biosurfactants produced by Candida antarctica. Biotechnology Letters, February 2000, vol. 22, no. 4, p. 313-316.

AGGELIS, G.; PAPADIOTIS, G. and KOMAITIS, M. Microbial fatty acid specificity. Folia Microbiologica, 1997, vol. 42, no. 2, p. 117-120.

ALONSO, F.O.M.; OLIVEIRA, E.B.L.; DELLAMORAORTIZ, G.M. and PEREIRA-MEIRELLES, F.V. Improvement of lipase production at different stirring speeds and oxygen levels. Brazilian Journal of Chemical Engineering, January-March 2005, vol. 22, no. 1, p 9-18.

ATHENSTAEDT, Karin; JOLIVET, Pascale; BOULARD, Céline; ZIVY, Michel; NEGRONI, Luc; NICAUD, JeanMarc and CHARDOT, Thierry. Lipid particle composition of the yeast Yarrowia lipolytica depends on the carbon source. Proteomics, March 2006, vol. 6, no. 5, p. 14501459.
BARTH, G. and GAILLARDIN, C. Yarrowia lipolytica. In: WOLF, K. eds. Non conventional yeasts in biotechnology. Berlin, Springer-Verlag, 1996, p. 313-388.

BEDNARSKI, W.; ADAMCZAK, M.; KOWALEWSKAPIONTAS, J. and ZADERNOWSKI, R. Biotechnological methods for the up-grading and modification of animal waste fats. Acta Biotechnologica, 1994, vol. 14, no. 4, p. 387-393.

ČERTIK, M.; BALTESZOVA, L. and SAJBIDOR, J. Lipid formation and $\gamma$-linolenic acid production by Mucorales fungi grown on sunflower oil. Letters in Applied Microbiology, August 1997, vol. 25, no. 2, p. 101-105.

DALMAU, E.; MONTESINOS, J.L.; LOTTI, M. and CASAS, C. Effect of different carbon sources on lipase production by Candida rugosa. Enzyme and Microbial Technology, June 2000, vol. 26, no. 9-10, p. 657-663.

DAVIN, S. and QUILTY, B. Identification and characterisation of a yeast isolated from activated sludge capable of growth on tallow. In: QUILTY, B. ed. Biology and Environment: Proceedings of the Royal Irish Academy, 2001, vol. 101B, no. 3, p. 263.

DE FELICE, B.; PONTECORVO, G. and CARFAGNA, M. Degradation of waste waters from olive oil mills by Yarrowia lipolytica ATCC 20255 and Pseudomonas putida. Acta Biotechnologica, 1997, vol. 17, no. 3, p. 231-239.

DOMINGUEZ, Alberto; DEIVE, Francisco J.; SANROMÁN, M. Angeles and LONGO, María A. Effect of lipids and surfactants on extracellular lipase production by Yarrowia lipolytica. Journal of Chemical Technology and Biotechnology, November 2003, vol. 78, no. 11, p. 1166-1170.

FICKERS, P.; NICAUD, J.M.; GAILLARDIN, C.; DESTAIN, J. and THONART, P. Carbon and nitrogen sources modulate lipase production in the yeast Yarrowia lipolytica. Journal of Applied Microbiology, April 2004, vol. 96 , no. 4, p. 742-749.

FICKERS, P.; BENETTI, P.-H.; WACHÉ, Y.; MARTY, A.; MAUERSBERGER, S.; SMIT, M.S. and NICAUD, J.M. Hydrophobic substrate utilisation by the yeast Yarrowia lipolytica, and its potential applications. FEMS Yeast Research, April 2005a, vol. 5, no. 6-7, p. 527-543.

FICKERS, Patrick; FUDALEJ, Franck; NICAUD, JeanMarc; DESTAIN, Jacqueline and THONART, Phillipe. Selection of new over-producing derivatives for the improvement of extracellular lipase production by the nonconventional yeast Yarrowia lipolytica. Journal of Biotechnology, February 2005b, vol. 115, no. 4, p. 379-386. 
FINOGENOVA, T.V.; MORGUNOV, I.G.; KAMZOLOVA, S.V. and CHERNYAVSKAYA, O.G. Organic acid production by the yeast Yarrowia lipolytica: A review of prospects. Applied Biochemistry and Microbiology, September 2005, vol. 41, no. 5, p. 418-425.

GALIOTOU-PANAYOTOU, Maria; KALANTZI, Ourania and AGGELIS, George. Modelling of simultaneous production of polygalacturonase and exopolysaccharide by Aureobasidium pullulans ATHUM 2915. Antonie Van Leeuwenhoek, February 1998, vol. 73, no. 2, p. 155-162.

HADEBALL, W. Production of lipase by Yarrowia lipolytica, I. Lipases from yeasts. Acta Biotechnologica, 1991, vol. 11, no. 2, p. 159-167.

KAMZOLOVA, Svetlana; MORGUNOV, Igor G.; AURICH, Andreas; PEREVOZNIKOVA, Oksana A.; SHISHKANOVA, Nadezda V.; STOTTMEISTER, Ulrich and FINOGENOVA, Tatiana V. Lipase secretion and citric acid production in Yarrowia lipolytica yeast grown on animal and vegetable fat. Food Technology and Biotechnology, 2005, vol. 43, no. 2, p. 113-122.

LEE, Inmok M.; HAMMOND, Earl G.; CORNETTE, James L. and GLATZ, Bonita A. Triacylglycerol assembly from binary mixtures of fatty acids by Apiotrichum curvatum. Lipids, December 1993, vol. 28, no. 12, p. 10551061.

LUO, Yi-Shan; NICAUD, Jean-Marc; VAN VELDHOVEN, Paul P. and CHARDOT, Thierry. The acyl-CoA oxidases from the yeast Yarrowia lipolytica: characterization of Aox 2p. Archives of Biochemistry and Biophysics, November 2002, vol. 407, no. 1, p. 32-38.

MANTZOURIDOU, Fani; TSIMIDOU, María and ROUKAS, Triantafillos. Performance of crude olive pomace oil and soybean oil during carotenoid production by Blakeslea trispora in submerged fermentation. Journal of Agricultural and Food Chemistry, April 2006, vol. 54, no. 7 , p. 2575-2581.

MAUERSBERGER, Stephan; WANG, Hui-Jie; GAILLARDIN, Claude; BARTH, Gerold and NICAUD, Jean-Marc. Insertional mutagenesis in the $n$-alkaneassimilating yeast Yarrowia lipolytica: Generation of tagged mutations in genes involved in hydrophobic substrate utilization. Journal of Bacteriology, September 2001, vol. 183 , no. 17 , p. 5102-5109.

MLIČKOVÁ, Kateřina; ROUX, Emeline; ATHENSTAEDT, Karin; D'ANDREA, Sabine; DAUM, Günther; CHARDOT, Thierry and NICAUD, Jean-Marc. Lipid accumulation, lipid body formation, and acylcoenzyme A oxidases of the yeast Yarrowia lipolytica. Applied and Environmental Microbiology, July 2004, vol. 70, no. 7, p. 3918-3924.
MONTESINOS, J.L.; DALMAU, E. and CASAS, C. Lipase production in continuous culture of Candida rugosa. Journal of Chemical Technology and Biotechnology, July 2003, vol. 78, no. 7, p. 753-761.

MUSIAE, Izabela; RYMOWICZ, Waldemar and CIBIS, Edmund. Optimization of single-cell-biomass production by Yarrowia lipolytica using response surface methodology and pulse method. Electronic Journal of Polish Agricultural Universities [online]. 2004, vol. 7, no. 1 Available from Internet: http://www.ejpau.media.pl/series/volume7/issue1/biotechno logy/art-02.html. ISSN 1505-0297.

NICAUD, Jean-Marc; MADZAK, Catherine; VAN DER BROEK, Peter; GYSLER, Christof; DUBOC, Philippe; NIEDERBERGER, Peter and GAILLARDIN, Claude. Protein expression and secretion in the yeast Yarrowia lipolytica. FEMS Yeast Research, August 2002, vol. 2, no. 3, p. 371-379.

OSWAL, N.; SARMA, P.M.; ZINJARDE, S.S. and PANT, A. Palm oil mill effluent treatment by a tropical marine yeast. Bioresource Technology, October 2002, vol. 85, no. 1, p. 35-37.

PAPANIKOLAOU, Seraphim; CHEVALOT, Isabelle; KOMAITIS, Michael; AGGELIS, George and MARC, Ivan. Kinetic profile of the cellular lipid composition in an oleaginous Yarrowia lipolytica capable of producing a cocoa-butter substitute from industrial fats. Antonie Van Leeuwenhoek, December 2001, vol. 80, no. 3-4, p. 215-224.

PAPANIKOLAOU, S.; MUNIGLIA, L.; CHEVALOT, I.; AGGELIS, G. and MARC, I. Yarrowia lipolytica as a potential producer of citric acid from raw glycerol. Journal of Applied Microbiology, April 2002, vol. 92, no. 4, p. 737744.

PAPANIKOLAOU, Seraphim and AGGELIS, George. Selective uptake of fatty acids by the yeast Yarrowia lipolytica. European Journal of Lipid Science and Technology, 2003, vol. 105, no. 11, p. 651-655.

PEREIRA-MEIRELLES, Fatima V.; ROCHA-LEÃO, Maria H.M. and SANT'ANNA, Geraldo L. A stable lipase from Candida lipolytica: cultivation conditions and crude enzyme characteristics. Applied Biochemistry and Biotechnology - Part A: Enzyme Engineering and Biotechnology, 1997, vol. 63-65, no. 1-3, p. 73-85.

PEREIRA-MEIRELLES, Fatima V.; ROCHA-LEÃO, Maria H.M. and SANT'ANNA, Geraldo L. Lipase location in Yarrowia lipolytica cells. Biotechnology Letters, January 2000, vol. 22, no. 1, p. 71-75.

PEREZ-CAMPO, Flor Maria and DOMINGUEZ, Angel. Factors affecting the morphogenetic switch in Yarrowia 
lipolytica. Current Microbiology, December 2001, vol. 43, no. 6, p. 429-433.

PIGNEDE, Georges; WANG, Hui-Jie; FUDALEJ, Franck; SEMAN, Michel; GAILLARDIN, Claude and NICAUD, Jean-Marc. Autocloning and amplification of LIP2 in Yarrowia lipolytica. Applied and Environmental Microbiology, August 2000, vol. 66, no. 8, p. 3283-3289.

RATLEDGE, C. Yeasts, moulds, algae and bacteria as sources of lipids. In: KAMEL, B.S. and KAKUDA, Y. eds. Technological advances in improved and alternative sources of lipids. London, Blackie academic and professional, 1994, p. 235-291.

RUIZ-HERRERA, José and SENTANDREU, Rafael. Different effectors of dimorphism in Yarrowia lipolytica. Archives of Microbiology, December 2002, vol. 178, no. 6, p. 477-483.

SHARMA, Rohit; CHISTI, Yusuf and BANERJEE, Uttam Chand. Production, purification, characterization and application of lipases. Biotechnology Advances, December 2001, vol. 19, no. 8, p. 627-662.

SZCZĘSNA-ANTCZAK, Miroslawa; ANTCZAK, Tadeusz; PIOTROWICZ-WASIAK, Magdalena; RZYSKA, Malgorzata; BINKOWSKA, Nina and BIELECKI, Stanislaw. Relationships between lipases and lipids in mycelia of two Mucor strains. Enzyme and Microbial Technology, October 2006, vol. 39, no. 6, p. 1214-1222.

TAN, K.H. and GILL, C.O. Batch growth of Saccharomycopsis lipolytica on animal fats. Applied Microbiology and Biotechnology, March 1985, vol. 21, no. 5, p. 292-298.

ZINJARDE, Smita; PANT, Aditi and DESHPANDE, Mukund V. Dimorphic transition in Yarrowia lipolytica isolated from oil-polluted seawater. Mycological Research, 1998, vol. 102, p. 553-558. 